\title{
RESPONSE OF ACTINOMYCETES, PHOSPHATASES AND UREASE TO SOIL CONTAMINATION WITH HERBICIDES
}

\author{
REAKCJA PROMIENIOWCÓW, FOSFATAZ I UREAZY \\ NA ZANIECZYSZCZENIE GLEBY HERBICYDAMI
}

\begin{abstract}
A laboratory experiment was completed to determine the effect of the herbicides Alister Grande 190 OD, Fuego 500 SC and Lumax 537.5 SE on counts of actinomycetes as well as the activity of enzymes and their resistance to herbicides. Sandy loam was mixed with appropriate doses of the herbicides, such as: 0 - the control, 1 - technological dose and doses 20-, 40-, 80- and 160-fold higher than recommended. On day 20, 40, 80 and 160 , counts of actinomycetes and activity of urease, acid phosphatase and alkaline phosphatase were determined. For 160 days, soil was incubated at $25^{\circ} \mathrm{C}$ and its moisture content was maintained on a constant level equal $50 \%$ of water capillary capacity. On days 20 and 80 of the experiment, the ecophysiological (EP) and colony development (CD) indices were computed. Additionally, the resistance (RS) of enzymes to the herbicides was assessed on day 20 and their resilience index (RL) was determined on day 160. It has been found out that soil contamination with herbicides contributed to elevated counts of actinomycetes. The highest number of these microorganisms was observed in soil with Lumax 537.5 SE, and the lowest one appeared in soil with Alister Grande 190 OD. The CD for actinomycetes was the highest in treatments with Fuego 500 SC and the highest EP was determined in soil with Alister Grande 190 OD. Application of the herbicides in doses from 20- to 160-fold higher than recommended by the manufacturer significantly increased the activity of acid and alkaline phosphatases. With respect to the activity of urease, the herbicides produced variable effects. The strongest inhibitory effect on the activity of urease was produced by Fuego 500 SC, which reduced the activity of this enzyme by $13.39 \%$ when added to soil in a dose exceeding by 160 -fold the recommended rate. The RS of the enzymes to the herbicides ranged from 0.461 to 0.955 . Urease was the most tolerant to soil contamination with the herbicides.
\end{abstract}

Keywords: herbicides, soil contamination, numbers of actinomycetes, activity of enzymes, soil resistance to herbicides

\section{Introduction}

Herbicides are chemical substances widely used to control weeds. However, some of these preparations can become dangerous to the environment due to their persistence and harmful effect on living organisms. When permeating soil in an uncontrollable manner, herbicides can be absorbed by roots of agricultural crops and then be transferred through

\footnotetext{
${ }^{1}$ University of Warmia and Mazury in Olsztyn, pl. Łódzki 3, 10-727 Olsztyn, Poland, phone +48 895234835

*Corresponding author: m.bacmaga@uwm.edu.pl
} 
subsequent links in a trophic chain. In soil, herbicides undergo biodegradation, a complex process which involves microorganisms able to degrade chemical compounds [1, 2]. Actinomycetes belong to a group of microorganisms which play an important role in decomposition of various chemical substances and participate in carbon cycling and formation of humic compounds in soil $[3,4]$.

Being a dynamic, live system, soil also contains enzymes, whose reactions depend on a number of factors, including soil contamination [5]. Among the key soil enzymes are hydrolases. Changes which they are exposed to due to different factors are most often assessed according to the activity of phosphatases and urease [6].

Phosphatases belong to periplasmic enzymes, which catalyze hydrolysis of organic phosphorus bonds. They are also employed in evaluation of the rate of mineralization of phosphorus compounds in soil and are responsible for the phosphorus budget in plants. In soil, these enzymes are secreted mainly by microorganisms, soil fauna and plant roots. In turn, urease is an enzyme responsible for the metabolism of organic nitrogen in soil. Urease catalyzes the hydrolysis of urea in soil, inducing formation of carbon dioxide and ammonia. Owing to its activity, nitrogen found in soil becomes available to plants. Urease attains the highest activity under aerobic conditions and becomes more active as the population of soil-borne microorganisms grows [7].

For ecologists, the role of microorganisms and soil enzymes is extremely important because they are essential to capture and describe changes which occur in soil in response to a variety of anthropogenic factors [8].

The objective of the present study has been to evaluate the effect produced by three herbicides: Alister Grande 190 OD, Fuego 500 SC and Lumax 537.5 SE, on numbers and diversity of actinomycetes as well as the activity of acid phosphatase, alkaline phosphatase and urease and the resistance of these enzymes to the herbicides.

\section{Materials and methods}

\section{Soil}

The soil used in the experiment had texture characteristic of sandy loam (72\% of sand fraction, $7 \%$ of silt fraction and $21 \%$ of loam fraction), and the following values of physicochemical characteristics: 7.0 of $\mathrm{pH}_{\mathrm{KCl}}, 8.00 \mathrm{mmol}(+) \mathrm{kg}^{-1}$ of hydrolytic acidity, $111.00 \mathrm{mmol}(+) \mathrm{kg}^{-1}$ of total exchangeable bases and $7.05 \mathrm{~g} \mathrm{~kg}^{-1}$ of the content of organic carbon.

Before the experiment was set up, the soil was passed through a $2 \mathrm{~mm}$ mesh sieve in order to establish the basic physicochemical properties of soil. The soil's grain size composition was determined with the areometric method: the $\mathrm{pH}$ was assessed by potentiometry in $\mathrm{KCl}$ aqueous solution of the concentration of $1 \mathrm{~mol} \mathrm{dm}^{-3}$; hydrolytic acidity (Hh) and total exchangeable bases (S) were assessed according to Kappen's method [9] and the content of organic carbon $\left(\mathrm{C}_{\text {org }}\right)$ was tested by Tiurin's method [10].

\section{Herbicides}

In a laboratory experiment, soil samples taken from the arable and humic horizon were tested to determine the effect of the herbicides Alister Grande 190 OD, Fuego 500 SC and Lumax 537.5 SE on the biological activity of soil. Table 1 contains a specification of some characteristics of the herbicides. 
Specification characteristics of the applied herbicides

\begin{tabular}{|c|c|c|c|}
\hline \multirow{2}{*}{ Name of herbicide } & \multicolumn{2}{|c|}{ Active ingredient } & \multirow{2}{*}{$\begin{array}{c}\text { Recommended dose } \\
{\left[\mathrm{dm}^{3} \mathrm{ha}^{-1}\right]} \\
\end{array}$} \\
\hline & Name & {$\left[\mathrm{g} \mathrm{kg}^{-1}\right]$} & \\
\hline Alister Grande 190 OD & $\begin{array}{c}\text { diflufenican } \\
\text { iodosulfuron-methyl sodium } \\
\text { mesosulfuron methyl }\end{array}$ & $\begin{array}{l}180.0 \\
4.500 \\
6.000 \\
\end{array}$ & 0.900 \\
\hline Fuego $500 \mathrm{SC}$ & metazachlor & 500.0 & 2.500 \\
\hline Lumax 537.5 SE & $\begin{array}{l}\text { terbuthylazine } \\
\text { mesotrione } \\
\text { s-metolachlor }\end{array}$ & $\begin{array}{l}187.5 \\
37.50 \\
312.5\end{array}$ & $3.500-4.000$ \\
\hline
\end{tabular}

\section{Experimental design}

Batches of $100 \mathrm{~g}$ of sandy loam, mixed with one of the three herbicides in the following doses: optimal, 20-, 40-, 80- and 160-fold higher than recommended, were placed in $150 \mathrm{~cm}^{3}$ beakers. Doses of the herbicides were re-calculated per $1 \mathrm{~kg}$ of soil. The dose recommended by the manufacturer for each herbicide was: $0.300 \mathrm{~mm}^{3} \mathrm{~kg}^{-1}$ for Alister Grande $190 \mathrm{OD}, 0.833 \mathrm{~mm}^{3} \mathrm{~kg}^{-1}$ for Fuego $500 \mathrm{SC}$ and $1.250 \mathrm{~mm}^{3} \mathrm{~kg}^{-1}$ for Lumax 537.5 SE. The control consisted of samples without the herbicides. The experiment was performed with three replications. For 20, 40, 80 and 160 days, the soil was incubated in an incubator at constant temperature of $25^{\circ} \mathrm{C}$, maintaining the soil moisture content at $50 \%$ of water capillary capacity.

\section{Microbiological analysis}

On the set days, the following determinations were made numbers of actinomycetes by the plating method on Kuster and Williams medium with added nystatin and actidione [11]. Petri plates were incubated for 7 days at $28^{\circ} \mathrm{C}$ and then, using a colony counter, the number of colony forming units (cfu) in $1 \mathrm{~kg} \mathrm{d.m.} \mathrm{of} \mathrm{soil} \mathrm{in} \mathrm{each} \mathrm{treatment} \mathrm{was} \mathrm{established.}$ Additionally, on days 20 and 80, the number of colonies of actinomycetes cultured in ten days was checked. Based on these data, the ecophysiological index (EP) of actinomycetes was calculated from the formula given by De Leij et al [12] and the colony development index (CD) was derived from the formula proposed by Sarathchandra et al [13].

\section{Enzymatic analysis}

On the set days, the following determinations were made:

- Activity of acid phosphatase (EC 3.1.3.2) and alkaline phosphatase (EC 3.1.3.1) by the method worked out by Alef et al [14] using disodium 4-nitrophenylsulphate as a substrate. The amount of 4-nitrophenol (PNP) produced from hydrolysis of disodium 4-nitropehylsulphate was measured on a Perkin-Elmer Lambda 25 spectrophotometer at the wavelength of $\lambda=410 \mathrm{~nm}$ (the activity of expressed in mmol PNP kg-1 d.m. $\mathrm{h}^{-1}$ ).

- Activity of urease (EC 3.5.1.5) according to Alef and Nannipieri [15], using urea as a substrate and expressing the activity in mmol N-NH $\mathrm{Ng}^{-1} \mathrm{~d} . \mathrm{m} . \mathrm{h}^{-1}$. The activity of the enzyme was determined colorimetrically by measuring extinction of produced ammoniated mercury(II) iodide at the wavelength of $\lambda=410 \mathrm{~nm}$. 
- The RS index of the soil enzymes to the herbicides on day 20 according to Orwin and Wardle [16].

- $\quad$ The RS index on day 160 according to Orwin and Wardle [16].

\section{Statistical analysis}

All the results were processed statistically by applying the ANOVA analysis of variance from the Statistica software [17] and Duncan's multiple range test. Statistical differences are given at the level of significance $p=0.01$. Results of microbiological and biochemical determinations are given as means for each determination day.

\section{Results}

\section{Microbes numbers}

Soil pollution with the herbicides modified numbers of actinomycetes (Table 2). Alister Grande 190 OD had the most destructive effect on the growth of these microorganisms. In the highest dose (160-fold higher than recommended), it depressed their number by $13.72 \%$ versus the control. Fuego $500 \mathrm{SC}$ introduced to soil in the same dose did not cause significant changes in the growth of actinomycetes. Under the influence of Lumax 537.5 SE, counts of atcinomycetes tended to increase when the herbicide had been applied in excessive doses, eg the dose 40 -fold higher than recommended caused an increase in the number of actinomyecetes by $20.79 \%$ compared to the control.

Table 2

Numbers of actinomycetes in soil contaminated with herbicides, $\mathrm{cfu} 10^{9} \cdot \mathrm{kg}^{-1} \mathrm{~d} . \mathrm{m}$. of soil

\begin{tabular}{|c|c|c|c|}
\hline Herbicide dose* & Alister Grande 190 OD & Fuego 500 SC & Lumax 537.5 SE \\
\hline 0 & 7.697 & 7.697 & 7.697 \\
\hline 1 & 7.584 & 6.635 & 6.987 \\
\hline 20 & 7.563 & 7.765 & 7.433 \\
\hline 40 & 7.156 & 7.735 & 8.069 \\
\hline 80 & 7.146 & 7.872 & 9.297 \\
\hline 160 & 6.641 & 7.483 & 8.861 \\
\hline $\bar{x}$ & 7.298 & 7.531 & 8.057 \\
\hline$r$ & -0.962 & 0.224 & 0.796 \\
\hline LSD $_{0.01}^{* *}$ & \multicolumn{2}{|c|}{$\mathrm{a}-0.194 ; \mathrm{b}-0.274 ; \mathrm{ab}-0.474$} \\
\hline
\end{tabular}

* 0 - control (not contaminated with herbicides), 1 - dose recommended by the manufacturer, doses higher than the recommended one by 20-, 40-, 80- and 160-fold.

** $\mathrm{LSD}_{00.1}$ for: $\mathrm{a}$ - type of herbicide, $\mathrm{b}$ - dose of herbicide, $\mathrm{ab}$ - interaction factors, $r$ - correlation coefficient.

The ecophysiological index (EP) of actinomycetes depended on the type and dose of a herbicide (Table 3). The EP ranged from 0.799 do 0.822 in soil with Alister Grande $190 \mathrm{OD}$, from 0.709 to 0.810 with Fuego $500 \mathrm{SC}$, and from 0.776 to 0.826 with Lumax 537.5 SE. The highest EP of actinomycetes was noticed in soil with Alister Grande 190 OD ( 0.808 on average) and the lowest one - in soil with Fuego 500 SC (0.744 on average).

The herbicides also affected the CD of actinomycetes (Table 4). These preparations, when applied in excessive amounts, caused an increase in the CD relative to the control. The highest value of the CD index was found in samples with the herbicide Fuego 500 SC 
(an average 33.771), lower in soil with Lumax 537.5 SE (an average 31.754) and the lowest in samples with Alsiter Grande 190 OD (an average 30.111).

Table 3

Ecophysiological diversity (EP) index for actinomycetes in soil contaminated with herbicides

\begin{tabular}{|c|c|c|c|}
\hline Herbicide dose* & Alister Grande 190 OD & Fuego 500 SC & Lumax 537.5 SE \\
\hline 0 & 0.810 & 0.810 & 0.810 \\
\hline 1 & 0.799 & 0.743 & 0.776 \\
\hline 20 & 0.822 & 0.709 & 0.790 \\
\hline 40 & 0.814 & 0.735 & 0.791 \\
\hline 80 & 0.804 & 0.735 & 0.788 \\
\hline 160 & 0.800 & 0.731 & 0.826 \\
\hline $\bar{x}$ & 0.808 & 0.744 & 0.797 \\
\hline$r$ & -0.416 & -0.360 & 0.643 \\
\hline LSD $_{0.01}^{* * *}$ & \multicolumn{2}{|c|}{$\mathrm{a}-0.011 ; \mathrm{b}-0.016 ; \mathrm{ab}-0.028$} \\
\hline
\end{tabular}

*explanation see Table 2

Colony development (CD) index for actinomycetes in soil contaminated with herbicide

Table 4

\begin{tabular}{|c|c|c|c|}
\hline Herbicide dose* & Alister Grande 190 OD & Fuego 500 SC & Lumax 537.5 SE \\
\hline 0 & 29.694 & 29.694 & 29.694 \\
\hline 1 & 32.267 & 34.045 & 32.961 \\
\hline 20 & 29.146 & 35.269 & 32.022 \\
\hline 40 & 29.508 & 34.977 & 31.784 \\
\hline 80 & 30.144 & 34.035 & 32.496 \\
\hline 160 & 29.908 & 34.609 & 31.569 \\
\hline $\bar{x}$ & 30.111 & 33.771 & 31.754 \\
\hline$r$ & -0.209 & 0.369 & 0.108 \\
\hline LSD $_{0.01}^{* *}$ & \multicolumn{3}{|c|}{$\mathrm{a}-0.451 ; \mathrm{b}-0.638 ; \mathrm{ab}-1.105$} \\
\hline
\end{tabular}

*explanation see Table 2

\section{Enzymatic activity}

Soil contamination with the herbicides significantly affected the activity of acid phosphatase (Table 5). The tested herbicides had positive influence on the activity of acid phosphatase. The highest dose (160-fold higher than recommended) raised the activity of this enzyme by $10.23 \%$ (Alister Grande 190 OD), $7.26 \%$ (Fuego 500 SC) and $20.61 \%$ (Lumax 537.5 SE) versus the control soil. The highest activity of acid phosphatase was observed in the treatments with Lumax 537.5 SE (on average $1.473 \mathrm{mmol} \mathrm{PNP} \mathrm{kg}{ }^{-1} \mathrm{~d} . \mathrm{m}^{-1} \mathrm{~h}^{-1}$ of soil), and the lowest one - in soil with Alister Grande 190 OD (on average 1.446 mmol PNP kg${ }^{-1}$ d.m. $\mathrm{h}^{-1}$ of soil).

The resistance of acid phosphatase in soil contaminated with the herbicides was varied and primarily depended on the type of a tested chemical (Table 6). Acid phosphatase was most resistant to Alister Grande 190 OD, the finding that was manifested by the highest average value of the RS index, such as 0.778 . The resistance of this enzyme to the other two herbicides was slightly weaker. The RS towards Lumax 537.5 SE was 0.716 and towards Fuego 500 SC - 0.664.

Soil contamination with the herbicides also caused lasting changes in the activity of acid phosphatase, an effect evidenced by the values of the resilience index (Table 7). Acid 
phosphatase restored its original activity most quickly in soil with Fuego 500 SC (0.118), less so in soil with Alister Grande 190 OD (-0.032) and most slowly in soil with Lumax 537.5 SE (-0.134). The RL index for acid phosphatase was also affected by doses of the tested herbicides. In respect of Alister Grande 190 OD and Fuego 500 SC, a rate 20-fold higher than recommended caused the biggest changes, with the values of the RL index being -0.281 and -0.436 , respectively. Weaker dependences were noticed in samples treated with Lumax 537.5 SE. The strongest influence on acid phosphatase was produced by the dose 160 -fold higher than the optimal one $(-0.597)$.

Table 5

Activity of acid phosphatase in soil contaminated with herbicides [mmol PNP kg ${ }^{-1} \mathrm{~d} . \mathrm{m} . \mathrm{h}^{-1}$ ]

\begin{tabular}{|c|c|c|c|}
\hline Herbicide dose* & Alister Grande 190 OD & Fuego 500 SC & Lumax 537.5 SE \\
\hline 0 & 1.281 & 1.281 & 1.281 \\
\hline 1 & 1.555 & 1.577 & 1.414 \\
\hline 20 & 1.497 & 1.554 & 1.450 \\
\hline 40 & 1.448 & 1.519 & 1.473 \\
\hline 80 & 1.448 & 1.391 & 1.675 \\
\hline 160 & 1.412 & 1.374 & 1.545 \\
\hline $\bar{x}$ & 1.446 & 1.449 & 1.473 \\
\hline$r$ & -0.082 & -0.323 & 0.670 \\
\hline LSD $_{0.01} * *$ & \multicolumn{3}{|c|}{$\mathrm{a}-0.023 ; \mathrm{b}-0.033 ; \mathrm{ab}-0.057$} \\
\hline
\end{tabular}

*explanation see Table 2

Table 6

Resistance index (RS) of acid phosphatase in soil contaminated with herbicides on day 20 of the experiment

\begin{tabular}{|c|c|c|c|}
\hline Herbicide dose* & Alister Grande 190 OD & Fuego 500 SC & Lumax 537.5 SE \\
\hline 1 & 0.789 & 0.881 & 0.837 \\
\hline 20 & 0.863 & 0.859 & 0.691 \\
\hline 40 & 0.591 & 0.500 & 0.461 \\
\hline 80 & 0.821 & 0.520 & 0.696 \\
\hline 160 & 0.826 & 0.560 & 0.896 \\
\hline $\bar{x}$ & 0.778 & 0.664 & 0.716 \\
\hline$r$ & 0.197 & -0.641 & 0.391 \\
\hline
\end{tabular}

*explanation see Table 2

Table 7

Resilience index (RL) of acid phosphatase in soil contaminated with herbicides on day 160 of the experiment

\begin{tabular}{|c|c|c|c|}
\hline Herbicide dose* & Alister Grande 190 OD & Fuego 500 SC & Lumax 537.5 SE \\
\hline 1 & -0.140 & -0.333 & -0.257 \\
\hline 20 & -0.281 & -0.436 & 0.027 \\
\hline 40 & 0.361 & 0.336 & 0.363 \\
\hline 80 & -0.062 & 0.513 & -0.207 \\
\hline 160 & -0.038 & 0.509 & -0.597 \\
\hline $\bar{x}$ & -0.032 & 0.118 & -0.134 \\
\hline$r$ & 0.121 & 0.779 & -0.633 \\
\hline
\end{tabular}

*explanation see Table 2

The tested herbicides had a stimulating effect on the activity of alkaline phosphatase, which was demonstrated by positive coefficients of the correlations between dose of the 
herbicides and activity of the enzyme (Table 8). The activity of alkaline phosphatase in sandy loam was higher by an average $7.66 \%$ in response to Alister Grande 190 OD, $10.24 \%$ under Fuego 500 SC and 10.81\% in soil treated with Lumax 537.5 SE (all added to soil in a dose 160-fold higher than recommended). Analogously to acid phosphatase, alkaline phosphatase was least active in soil with Alister Grande 190 OD (average 1.926 mmol PNP kg${ }^{-1}$ d.m. $\mathrm{h}^{-1}$ of soil).

Activity of alkaline phosphatase in soil contaminated with herbicides [mmol PNP kg ${ }^{-1} \mathrm{~d} . \mathrm{m} . \mathrm{h}^{-1}$ ]

\begin{tabular}{|c|c|c|c|}
\hline Herbicide dose* & Alister Grande 190 OD & Fuego 500 SC & Lumax 537.5 SE \\
\hline 0 & 1.748 & 1.748 & 1.748 \\
\hline 1 & 1.908 & 2.035 & 1.958 \\
\hline 20 & 1.914 & 1.999 & 1.975 \\
\hline 40 & 1.909 & 1.946 & 1.927 \\
\hline 80 & 1.988 & 1.902 & 1.954 \\
\hline 160 & 1.882 & 1.927 & 1.937 \\
\hline $\bar{x}$ & 1.892 & 1.926 & 1.917 \\
\hline$r$ & 0.305 & 0.020 & 0.305 \\
\hline$L^{*}$ & \multicolumn{2}{|c|}{$\mathrm{a}-0.014 ; \mathrm{b}-0.019 ; \mathrm{ab}-0.033$} \\
\hline
\end{tabular}

*explanation see Table 2

The resistance of alkaline phosphatase to excessive amounts of the herbicides in soil was similar in all treatments (Table 9). However, the highest RS index was calculated for soil contaminated with Alister Grande 190 OD (0.895), followed by Fuego 500 SC (0.848) and the lowest value was determined in treatments with Lumax 537.5 SE (0.792). The highest dose (160-fold higher than recommended) induced the biggest changes. Thus, the value of the RS was $12.25 \%$ lower in response to Alister Grande 190 OD and $6.47 \%$ lower due to Lumax 537.5 SE. In contrast, the herbicide Fuego 500 SC produced an almost negligible effect on the RS.

Table 9 Resistance index (RS) of alkaline phosphatase in soil contaminated with herbicides on day 20 of the experiment

\begin{tabular}{|c|c|c|c|}
\hline Herbicide dose* & Alister Grande 190 OD & Fuego 500 SC & Lumax 537.5 SE \\
\hline 1 & 0.939 & 0.858 & 0.881 \\
\hline 20 & 0.899 & 0.834 & 0.733 \\
\hline 40 & 0.892 & 0.824 & 0.769 \\
\hline 80 & 0.922 & 0.865 & 0.801 \\
\hline 160 & 0.824 & 0.860 & 0.824 \\
\hline $\bar{x}$ & 0.895 & 0.848 & 0.792 \\
\hline$r$ & -0.769 & 0.442 & -0.058 \\
\hline
\end{tabular}

*explanation see Table 2

The herbicides used in elevated rates caused certain modifications in soil. The highest RL index was recorded in soil samples with Fuego 500 SC, while the lowest one was determined in treatments with Alister Grande 190 OD (Table 10). Values of this index were 0.366 and 0.126 , respectively. The dose of a herbicide also had a significant effect on the value of the RL index for alkaline phosphatase. Regarding Alister Grande 190 OD, the highest RL was achieved when the dose of this herbicide introduced to soil was 80-fold 
higher than recommended (-0.020). Fuego 500 SC added to soil in a dose 160-fold higher than the optimal one reduced the value of the RL from 0.304 to -0.241 . In turn, Lumax 537.5 SE caused the biggest changes when applied in a dose recommended by the manufacturer (the RL equalled 0.012).

Table 10 Resilience index (RL) of alkaline phosphatase in soil contaminated with herbicides on day 160 of the experiment

\begin{tabular}{|c|c|c|c|}
\hline Herbicide dose* & Alister Grande 190 OD & Fuego 500 SC & Lumax 537.5 SE \\
\hline 1 & -0.008 & 0.304 & 0.012 \\
\hline 20 & 0.214 & 0.534 & 0.597 \\
\hline 40 & 0.196 & 0.755 & 0.611 \\
\hline 80 & -0.020 & 0.476 & 0.316 \\
\hline 160 & 0.248 & -0.241 & 0.121 \\
\hline $\bar{x}$ & 0.126 & 0.366 & 0.331 \\
\hline$r$ & 0.377 & -0.733 & -0.273 \\
\hline
\end{tabular}

*explanation see Table 2

Urease proved to be very sensitive to soil contamination with herbicides (Table 11). Soil application of Fuego 500 SC caused inhibition of the activity of urease. The strongest inhibitory effect on urease was produced by a dose 160-fold higher than the optimal one, as it depressed the activity of this enzyme by $13.39 \%$ relative to the control. Urease also responded to excessive quantities of Alister Grande 190 OD. When this herbicide had been added to soil in a rate 40-fold higher than optimum, the activity of urease fell down by $6.97 \%$. Lumax 537.5 SE had the weakest effect on urease. Doses of this herbicide from the optimal one to 80 -fold higher than recommended only slightly stimulated the activity of urease. Its activity rose from 4.59 to $7.71 \%$ compared with the control.

Activity of urease in soil contaminated with herbicides [mmol N-NH $\mathrm{kg}^{-1} \mathrm{~d} \cdot \mathrm{m} . \mathrm{h}^{-1}$ ]

Table 11

\begin{tabular}{|c|c|c|c|}
\hline Herbicide dose* & Alister Grande 190 OD & Fuego 500 SC & Lumax 537.5 SE \\
\hline 0 & 0.545 & 0.545 & 0.545 \\
\hline 1 & 0.559 & 0.566 & 0.579 \\
\hline 20 & 0.515 & 0.572 & 0.587 \\
\hline 40 & 0.507 & 0.527 & 0.582 \\
\hline 80 & 0.527 & 0.494 & 0.570 \\
\hline 160 & 0.511 & 0.472 & 0.549 \\
\hline $\bar{x}$ & 0.527 & 0.529 & 0.569 \\
\hline$r$ & -0.578 & -0.915 & -0.392 \\
\hline$L_{0.01}^{* *}$ & \multicolumn{2}{|c|}{$\mathrm{a}-0.009 ; \mathrm{b}-0.013 ; \mathrm{ab}-0.022$} \\
\hline
\end{tabular}

*explanation see Table 2

By analyzing values of the RS, it can be concluded that urease was least resistant to the influence of Lumax 537.5 SE (Table 12), because the average value of the RS in soil polluted with this herbicide was 0.788 . Urease was slightly more tolerant to Fuego $500 \mathrm{SC}$ (average RS 0.856) and most tolerant to Alister Grande 190 OD (average 0.907). It was not only the type but also the dose of a herbicide that produced a significant effect on the RS for urease. For example, Alister Grande 190 OD applied in the highest dose (160-fold higher than recommended) had the strongest impact on the RS, reducing its value by $13.86 \%$. In 
turn, Fuego 500 SC and Lumax 537.5 SE introduced to soil in the highest doses (160-fold higher than the optimal one) raised the value of the RS by 13.01 and $23.90 \%$, respectively.

Table 12

Resistance index (RS) of urease in soil contaminated with herbicides on day 20 of the experiment

\begin{tabular}{|c|c|c|c|}
\hline Herbicide dose* & Alister Grande 190 OD & Fuego 500 SC & Lumax 537.5 SE \\
\hline 1 & 0.931 & 0.838 & 0.728 \\
\hline 20 & 0.955 & 0.805 & 0.735 \\
\hline 40 & 0.935 & 0.807 & 0.786 \\
\hline 80 & 0.912 & 0.883 & 0.791 \\
\hline 160 & 0.802 & 0.947 & 0.902 \\
\hline $\bar{x}$ & 0.907 & 0.856 & 0.788 \\
\hline$r$ & -0.935 & 0.909 & 0.977 \\
\hline
\end{tabular}

*explanation see Table 2

The herbicides led to lasting changes in the activity of urease (Table 13). The RL for urease was the lowest in soil with Alister Grande 190 OD $(-0.830)$ and the highest in samples with Lumax 537.5 SE (0.580). In respect of Fuego 500 SC, the RL for urease was 0.125. The greatest changes caused by Fuego 500 SC and Lumax 537.5 SE were observed when these herbicides had been added to soil in the highest doses (160-fold higher than recommended). Then, the RL values were the lowest: -0.579 and 0.188 , respectively. But it was the herbicide Alister Grande 190 OD introduced into soil in a dose 20-fold higher than recommended that caused the biggest change (the RL value was -0.926).

Resilience index (RL) of urease in soil contaminated with herbicides on day 160 of the experiment

\begin{tabular}{|c|c|c|c|}
\hline Herbicide dose* & Alister Grande 190 OD & Fuego 500 SC & Lumax 537.5 SE \\
\hline 1 & -0.877 & 0.538 & 0.832 \\
\hline 20 & -0.926 & 0.608 & 0.669 \\
\hline 40 & -0.883 & 0.360 & 0.510 \\
\hline 80 & -0.839 & -0.303 & 0.699 \\
\hline 160 & -0.626 & -0.579 & 0.188 \\
\hline $\bar{x}$ & -0.830 & 0.125 & 0.580 \\
\hline$r$ & 0.936 & -0.947 & -0.865 \\
\hline
\end{tabular}

*explanation see Table 2

\section{Discussion}

\section{Microbes numbers}

Soil microorganisms respond differently to contaminants which enter soil. Some do not tolerate even small amounts of herbicides, while others can stand their presence so that their numbers rise [18]. Higher multiplication of microorganisms in response to herbicides may be a result of microorganisms using up organic substances found in these preparations. In the present study, the three herbicides had a positive effect on counts of actinomycetes. Higher abundance of actinomycetes in soil with herbicides has also been indicated by Araŭjo et al [19] and Crouzet et al [20]. In turn, Kucharski and Wyszkowska [21] demonstrated that the herbicide Apyros 75 WG inhibited the growth of actinomycetes in soil polluted with this chemical. 
Ratcliff et al [22] state that poorer diversity of microorganisms leads to bigger changes in the soil environment than their depleted numbers. These researchers claim that improved diversity of microbes owing to production of appropriate enzymes can aid degradation of organic pollutants, including herbicides. A higher value of the $\mathrm{CD}$ index proves that the number of r-strategists increases, whereas a lower CD index indicates a growing number of $\mathrm{K}$-strategists. K-strategists are microorganisms which develop very well in an environment where other microorganisms are present, and which demonstrate better tolerance to stress factors, caused for example by herbicides. In contrast, r-strategists represent a group of microorganisms which grow very fast but only when easily assimilable substrates are available and presence of other, competitive microorganisms is limited [13]. This proves that changes in the environment can have a significant effect on the growth of microorganisms, both the ones growing fast and those which grow slowly. Cycon and Piotrowska-Seget [23], who analyzed the effect of the herbicide diuron (doses 1.5, 7.5 and $150 \mathrm{mg} \mathrm{kg}^{-1}$ of soil) on diversity of soil microorganisms, noticed its negative effect on the $\mathrm{EP}$ and CD. They observed that in all treatments polluted with diuron and in the control soil, K-strategists prevailed. And the strongest effect on the biodiversity of microorganisms was produced by the dose of $150 \mathrm{mg} \mathrm{kg}$-1 of soil. Similar results were reported by Cycon et al [24] from a study on the effect of the herbicide linuron applied in doses of 4, 20 and $400 \mathrm{mg} \mathrm{kg}^{-1}$ on the activity of microorganisms in loamy sand and sandy loam. These authors noticed that linuron introduced to soil in excessive quantities can disturb development of indigenous microorganisms in soil. Linuron added in a dose of $400 \mathrm{mg} \mathrm{kg}^{-1}$ induced dominance of K-strategists on day 1 and 14, while r-strategists dominated at 28 days. Similar results were reported by Ros et al [25] from an experiment on atrazine applied in doses of 10,100 and $1000 \mathrm{mg} \mathrm{kg}^{-1}$ of soil. Likewise, in the present study, Fuego 500 SC and Lumax 537.5 SE acted adversely on the diversity of actinomycetes. These herbicides also changed proportions between r-strategists and K-strategists to the advantage of the former.

\section{Enzymatic activity}

Herbicides introduced to soil in higher doses can also interfere with the activity of soil enzymes. Owing to their rapid response to soil pollutants, soil enzymes can serve as indicators of transformations which occur in a soil environment due to various stress factors [26-28]. Thus, determinations of the activity of soil enzymes, especially phosphatases and urease, are an appropriate indicator showing the influence of herbicides on the soil environment.

The results obtained from the present study show that the three herbicides produced various effects on the enzymatic activity of soil. Urease proves to be a very sensitive enzyme. In our experiment, its activity declined significantly in response to elevated doses of all the three herbicides. The inhibitory impact of a herbicide on the activity of urease has also been demonstrated by Yang-Fang et al [29], who tested mefenacet. Sukul [30] proved experimentally that metalaxyl introduced to soil in excessive quantities inhibited the activity of urease for 60 days. Kucharski and Wyszkowska [21] concluded that, next to dehydrogenases, urease was most sensitive to the herbicide Apyros 75 WG. Yao et al [31], however, did not report any evident changes in the activity of urease in soil treated with acetamipirid. Similar results were attained by Bacmaga et al [6], who tested the herbicide Aurora $40 \mathrm{WG}$. 
The activity of phosphatases is another good indicator of changes induced in soil by herbicides. Positive influence of Aurora $40 \mathrm{WG}$ on the activity of acid and alkaline phosphatases was observed by Baćmaga et al [6]. Also Kucharski and Wyszkowska [21] report that phosphatases, and especially alkaline phosphatase, were more tolerant to the effect produced by Apyros 75 WG. However, in another experiment Wyszkowska [32] the herbicide Treflen 480 EC produced a negative effect on the activity of acid and alkaline phosphatases. The adverse influence on the activity of both phosphatases was also demonstrated by Wyszkowska and Kucharski [33] when testing Triflurotox 250 EC.

Some herbicides cause persistent changes in the activity of phosphatases and urease [34]. In this study, acid phosphatase and alkaline phosphatase were most tolerant to the effect produced by Alister Grande 190 OD, whereas urease proved to be most resistant to Lumax 537.5 SE. Different effects produced by the tested herbicides on the enzymes are a result of their different chemical composition and different active ingredients.

\section{Conclusions}

1. Introduction of the herbicides Alister Grande 190 OD, Fuego $500 \mathrm{SC}$ and Lumax 537.5 SE into soil disturbed the microbiological and enzymatic balance of soil.

2. Increased doses tested preparations stimulated the multiplication of actinomycetes.

3. Higher than recommended doses of the herbicides caused a significant effect on values of the colony development (CD) and ecophysiological (EP) indices of actinomycetes. The diversity of these microorganisms was the highest in soil with Alister Grande 190 OD and the lowest in soil treated with Fuego 500 SC.

4. Excessive rates of the herbicides in soil stimulated the activity of acid and alkaline phosphatases but inhibited that of urease.

5. Urease proved to be most resistant to soil contamination with the herbicides, alkaline phosphatase was slightly less tolerant and acid phosphatase was most sensitive.

\section{Acknowledgements}

This study has been performed as part of the research project No N N305 386138 financed by the National Science Centre.

\section{References}

[1] Tao L, Yang H. Fluroxypyr biodegradation in soils by multiple factors. Environ Monit Assess. 2011;175:227-238. DOI: 10.1007/s10661-010-1508-2.

[2] Zhang HB, Luo YM, Zhao QG, Wong MH, Zhang GL. Residues of organochlorine pesticides in Hong Kong soils. Chemosphere. 2006;63:633-641. DOI: 10.1016/j.chemosphere.2005.08.006.

[3] Emmerling C, Liebner C, Haubold-Rosar M, Katzur J, Schvoder D. Impact of application of organic west materials of microbial and enzyme activities of nine soil in the lusetion coal mining region. Plant Soil. 2000;220:129-138. DOI: 10.1023/A:1004784525209.

[4] Frączek K, Kozdrój J. Assessment of airborne actinomycetes in subterranean and earth sanatoriums. Ecol Chem Eng S. 2013;20(1):151-161. DOI: 10.2478/eces-2013-0012.

[5] Slavík R, Julinová M, Labudíková M. Screening of the spatial distribution of risk metals in topsoil from an industrial complex. Ecol Chem Eng S. 2012;19(2):259-272. DOI: 10.2478/v10216-011-0020-0.

[6] Baćmaga M, Boros E, Kucharski J, Wyszkowska J. Enzymatic activity in soil contaminated with the Aurora 40 WG herbicide. Environ Protec Eng. 2012;38(1):91-102.

[7] Rahmansyah M, Antonius S, Sulistinah N. Phosphatase and urease instability caused by pesticides present in soil improved by grounded rice straw. J Agric Biol Sci. 2009;4(2):56-62. 
[8] Singh DK, Kumar S. Nitrate reductase, arginine deaminase, urease and dehydrogenase activities in natural soil (ridges with forest) and in cotton soil after acetamiprid treatments. Chemosphere. 2008;71:412-418. DOI: 10.1016/j.chemosphere.2007.11.0 05.

[9] Carter MR. Soil Sampling and Methods of Analysis. London: Canadian Soc Soil Sci, Lewis Publishers; 1993.

[10] Nelson DW, Sommers LE. Total carbon, organic carbon, and organic matter. In: Method of Soil Analysis: Chemical Methods. Sparks DL, editor. Madison, WI: Amer Soc Agronomy; 1996; 1201-1229.

[11] Parkinson D, Gray FRG, Williams ST. Methods of Studying Ecology of Soil Microorganism. IBP Handbook. Oxford and Edinburgh: Blackwell Scientific Publications; 1997; 19.

[12] De Leij FAAM, Whipps JM, Lynch JM. The use of colony development for the characterization of bacterial communities in soil and on roots. Microb Ecol. 1993;27:81-97.

[13] Sarathchandra SU, Burch G, Cox NR. Growth patterns of bacterial communites in the rhizoplane and rhizosphere of with clover (Trifolium repens L.) and perennial ryegrass (Lolium perenne L.) in long-term pasture. Appl Soil Ecol. 1997;6:293-299.

[14] Alef K, Nannipieri P, Trazar-Capeda C. Phosphatase activity. In: Methods in Applied Soil Microbiology and Biochemistry. Alef K, Nannipieri P, editors. London: Academic Press Harcourt Brace \& Company, Publishers; 1998; 335-344.

[15] Alef K, Nannipieri P. Urease activity. In: Methods in Applied Soil Microbiology and Biochemistry. Alef K, Nannipieri P, editors. London: Academic Press. Harcourt Brace \& Company, Publishers, 1998; 316-320.

[16] Orwin KH, Wardle DA. New indices for quantifying the resistance and resilience of soil biota to exogenous disturbances. Soil Biol Biochem. 2004;36:1907-1912. DOI: 10.1016/j.soilbio.2004.04.036.

[17] Statsoft, Inc, Statistica. Data Analysis Software System, version 9.1., $2010<\mathrm{http}$ ://www.statsoft.com.>.

[18] Mukherjee P, Alam S, Sardar D, Pahari A, Roy S, Chowdhury A. Persistence and dissipation of linuron (Afalon-50 WP) in pea cropped soil and its effect on soil microorganisms. Bull Environ Contam Toxicol. 2006;76(3):407-414. DOI: 10.1007/s00128-006-0936-8.

[19] Araújo ASF, Monteiro RTR, Abarkeli RB. Effect of glyphosate on the microbial activity of two Brazilian soil. Chemosphere. 2003;52:799-804. DOI: 10.1016/S0045-6535(03)00266-2.

[20] Crouzet O, Batisson I, Besse-Hoggan P, Bonnemoy F, Bardot C, Poly F, et al. Response of soil microbial communities to the herbicide mesotrione: A dose-effect microcosm approach. Soil Biol Biochem. 2010;42:193-202. DOI: 10.1016/j.soilbio.2009.10.016.

[21] Kucharski J, Wyszkowska J. Biological properties of soil contaminated with the herbicyde Apyros 75 WG. J Elem. 2008;13(3):357-371.

[22] Ratcliff AW, Busse MD, Shestak CJ. Changes in microbial community structure following herbicide (glyphosate) addition to forest soils. Appl Soil Ecol. 2006;34:114-124. DOI: 10.1016/j.apsoil.2006.03.002.

[23] Cycoń M, Piotrowska-Seget Z. Changes in bacterial diversity and community structure following pesticides addition to soil estimated by cultivation technique. Ecotoxicology. 2009;18(5):632-642. DOI: 10.1007/s10646-009-0321-6.

[24] Cycoń M, Piotrowska-Seget Z, Kozdrój J. Linuron effects on microbiological characteristics of sandy soils as determined in a pot study. Ann Microbiol. 2010;60(3):439-449. DOI: 10.1007/s13213-010-0061-0.

[25] Ros M, Goberna M, Moreno JL, Hernandez T, Garcı́a C, Insam H, et al. Molecular and physiological bacterial diversity of a semi-arid soil contaminated with different levels of formulated atrazine. Appl Soil Ecol. 2006;34:93-102. DOI: 10.1016/j.apsoil.2006.03.010.

[26] Megharaj M, Kantachote D, Singleton I, Naidu R. Effect of long-term contamination of DDT on soil microflora with special reference to soil algae and algae transformation DDT. Environ Pollut. 2000;109:35-42. DOI: 10.1016/S0269-749(99)00231-6.

[27] Cai X, Sheng G, Liu W. Degradation and detoxication of acetochlor in soils treated by organic and thiosulfate amendments. Chemosphere. 2007;66:286-292. DOI: 10.1016/j.chemosphere.2006.05.011.

[28] Nweke CO, Ntinugwa C, Obah IF, Ike SC, Eme GE, Opara EC, et al. In vitro effects of metals and pesticides on dehydrogenase activity in microbial community of cowpea (Vigna unguiculata) rhizoplane. Afr J Biotechnol. 2007;6(3):290-295.

[29] Yang-Fang Y, Hang M, Xiang-Chi Z. Effects of mefenacet on microbial respiration and enzyme activities in paddy soil. Acta Pedol Sin. 2004;41:93-96.

[30] Sukul P. Enzymatic activities and microbial biomass in soil as influenced by metaxyl residues. Soil Biol Biochem. 2006;38:320-326. DOI: 10.1016/j.soilbio.2005.05.009.

[31] Yao X, Min H, Lii Z, Yuan H. Influence of acetamipirid on soil enzymatic activities and respiration. Eur J Soil Biol. 2006;42:120-126. DOI: 10.1016/j.ejsobi.2005.12.001. 
[32] Wyszkowska J. Effect of soil contamination with Treflan 480 EC on biochemical properties of soil. Pol J Environ Stud. 2002;11(1):71-77.

[33] Wyszkowska J, Kucharski J. Biochemical and physicochemical properties of soil contaminated with herbicide Triflurotox 250 EC. Pol J Environ Stud. 2004;13(2):223-231.

[34] Bécaert V, Samson R, Deschênes L. Effect of 2,4-D contamination on soil functional stability evaluated using the relative soil stability index (RSSI). Chemosphere. 2006;64:1713-1721. DOI: 10.1016/j.chemosphere.2006.01.008.

\title{
REAKCJE PROMIENIOWCÓW, FOSFATAZ I UREAZY NA ZANIECZYSZCZENIE GLEBY HERBICYDAMI
}

\author{
Katedra Mikrobiologii, Uniwersytet Warmińsko-Mazurski w Olsztynie
}

\begin{abstract}
Abstrakt: W doświadczeniu laboratoryjnym określono oddziaływanie herbicydów Alister Grande 190 OD, Fuego 500 SC i Lumax 537,5 SE na liczebność i różnorodność promieniowców, aktywność enzymów glebowych i ich oporność na herbicydy. Do gliny piaszczystej wprowadzono w odpowiednich obiektach środki chwastobójcze w następujących dawkach: 0 - kontrola, 1 - dawka technologiczna oraz dawki 20-, 40-, 80- i 160-krotnie większe. W 20, 40, 80 i 160 dniu oznaczono liczebność promieniowców oraz aktywność fosfatazy kwaśnej, fosfatazy alkalicznej i ureazy. Przez 160 dni glebę inkubowano w temperaturze $25^{\circ} \mathrm{C}$ i utrzymywano jej wilgotność na stałym poziomie 50\% kapilarnej pojemności wodnej. W 20 i 80 dniu trwania doświadczenia obliczono współczynnik ekofizjologicznej różnorodności promieniowców (EP) oraz indeks rozwoju kolonii (CD). Dodatkowo w 20 dniu określono współczynnik oporności (RS) enzymów na herbicydy, natomiast wskaźnik ich powrotu do stanu równowagi (RL) obliczono w 160 dniu. Stwierdzono, że zanieczyszczenie gleby herbicydami przyczyniło się do zwiększenia liczebności promieniowców. Największą liczbę tych drobnoustrojów zaobserwowano w glebie z herbicydem Lumax 537,5 SE, natomiast najmniejszą z Alister Grande 190 OD. Wartość wskaźnika CD dla promieniowców była najwyższa w obiektach z preparatem Fuego 500 SC, a współczynnika EP - z Alister Grande 190 OD. Zastosowanie herbicydów w dawce od 20 do 160-krotnie większej od dawki zalecanej przez producenta istotnie zwiększało aktywność fosfatazy kwaśnej i alkalicznej. W przypadku aktywności ureazy odnotowano zróżnicowany wpływ herbicydów. Największy inhibicyjny wpływ na aktywność ureazy wywierał preparat Fuego 500 SC, który zastosowany w dawce 160-krotnie większej zmniejszył jej aktywność o 13,39\%. Współczynnik oporności enzymów na działanie środków chwastobójczych wahał się od 0,461 do 0,955. Najbardziej oporna na zanieczyszczenie gleby herbicydami była ureaza.
\end{abstract}

Słowa kluczowe: herbicydy, zanieczyszczenie gleby, liczebność promieniowców, aktywność enzymów, oporność gleby na herbicydy 